\title{
The Influence of Training and Career Development to Employee Performance Among Academic Civities At Sekolah Tinggi Ilmu Ekonomi Muara
}

\author{
Sofia \\ Sekolah Tinggi Ilmu Ekonomi Muara Teweh, Indonesia \\ sofiatajeri@gmail.com \\ ${ }^{*}$ Corresponding Author
}

How to Cite : Sofia,S. (2020). The Influence of Training and Career Development to Employee Performance Among Academic Civities At Sekolah Tinggi IImu Ekonomi Muara. International Journal for Educational and Vocational Studies, 2 (8), 675-678. DOI: https://doi.org/10.29103/ijevs.v2i8.2758

\section{ARTICLE HISTORY}

Received: 4 July 2020

Revised: 13 July 2020

Accepted: 17 July 2020

KEYWORDS

Training;

Career Development;

Performance;

\begin{abstract}
One important factor in sustaining the company's existence in advancing quality and performance management is the mastery of capabilities possessed by human resources and the clarity of career development. A clean and healthy company is certainly due to good employee performance. Employee performance will improve if employees are given the training to improve their abilities and also a clear career development program. This study aims to determine the effect of training and career development on employee performance. The unit of analysis in this study is individual employees of academic civities. The population in this study is all employees of academic civities which amounted to 63 employees. The sampling technique in this study was carried out with saturated sampling technique. The data analysis technique used is multiple linear analysis. The results showed that training and career development both partially and simultaneously had a significant effect on employee performance.
\end{abstract}

This is an open access article under the CC-BY-SA license.

\section{INTRODUCTION}

Performance is the result of work and one's work behavior in a period achieved in carrying out tasks in accordance with responsibilities (Bagus, 2020). The performance is also a comparison of the results achieved with the participation of labor per unit time. In other words, performance is an expression of output, efficiency and effectiveness are often associated with productivity (Sulaksono, 2015).

Human resources are the most important part of every company (Trstenjak, M., \& Ćosić, 2018). Becauses of the human resources are a major part of the company, therefore a company must pay special attention to these resources. The type of attention needs to be given to human resources such as issuing regulations or policies that encourage employee performance improvement. For example education, training, career development, a conducive work environment and giving motivation. Based on this attention, employees are expected to maximize their work responsibilities.

The importance of training employees to improve performance. Employee is a blood stream of any business (Elnaga \& Imran, 2013). Naqvi, \& Khan (2013) stated the- training is the most important part of human resource management function on the effective use of human resources. Some benefits of the benefits of workforce training, including 1) Increase the quantity and quality productivity. 2) Reducing the study time needed employee order to reach acceptable performance standards. 3) Creating an attitude of loyalty and cooperation the more profitable. 4) Meet the needs of human resource planning. 5) Reducing the number and cost of accidents work. 6) Helping employees improve and their personal development (Hutajulu \& Supriyanto 2013).

Providing training to employees is something that must be done at a company (Wispandono, 2018). Through training employees will develop or explore the capabilities of a person so that they have the skills, ways of thinking and improving attitudes following what is needed by a company or a particular institution to solve problems. However Al-Khaled (2019) stated, It is important to take into consideration the importance of providing effective coordination to the employee. and enabling better team coordination and performance. Beside, Providing training can improve work performance and employee motivation and also as a basis for advising (Kemal, Suryadi, Rosyidi, 
2019). Previous studies provide evidence that there is a strong positive relationship between training and work perfomance (Sendawula et al,. 2018), (Memon et al,. 2016) The purpose of job training is to equip, improve and develop work skills or expertise, productivity and welfare of employees.

Career development is a self-development activities undertaken by a person to realize his personal career plan (Marwansyah, 2012). In other words, personal enhancements made to achieve a career plan. A company would want qualified employees whose

qualities increase every time because the progress of a person's career is not determined by the length of work, but from his competence. The way to be done by the company to increase career development to produce employees more qualified through education and training. If the employee's career is not considered, the employee's commitment to the organization becomes weak and will affect the employee's performance worse. (Lisdiani \& Ngatno 2017).

Based on the description above, the researcher wants to conduct research related to the performance of employees affected by training and career development with the aim of 1) to analyze whether the training affects the performance of the academic community, 2) to analyze whether career development affects the performance of the academic community, and 3) to analyze whether training and career development affect the performance of the Muara Teweh College of Economics.

\section{METHODS}

The population in this study were all academic community members, totalling 63 employees. The sample is part or representative of the population that is the source of the actual data studied are examples (Bajpai, 2009).). The sampling technique in this study was carried out with saturated sampling technique. Sampling with this technique because the entire population will be used as research samples.

The source of data in this research is primary data. The data is in the form of a questionnaire filled out by respondents. The questionnaire will be collected by researchers for data processing purposes. Data collection techniques used in this study are techniques by distributing questionnaire sheets directly to respondents. The distribution was carried out directly by researchers in the place of observation. The researcher directly distributes the questionnaire to the selected respondents in the study sample. This study uses a questionnaire model that is used by using a multicotomic questionnaire where the subject has 5 alternative responses using a Likert scale. This scale is related to the statement of attitude towards something that will be measured by the researcher. This scale will give respondents an idea about the size of their perception of the items in the questionnaire.

\section{RESULTS AND DISCUSSIONS}

Characteristics of respondents based on gender male respondents numbered 41 people (65.1\%) and female respondents numbered 22 people $(34.9 \%)$. For the status of respondents, respondents with married status numbered 24 people and not married numbered 39 people. For age characteristics, respondents aged less than 20 years amounted to 0 people, respondents aged 20 to 29 years totaling 29 people, respondents aged 29 to 39 years totaling 23 people, respondents with ages 39 to 49 years totaling 11 people, and respondents with more than 49 years of age totaling 0 people. For the characteristics of education, respondents with high school education amounted to 3 people, respondents with D3 education totaled 21 people, respondents with $\mathrm{S} 1$ education totaled 37 people, and respondents with S2 education totaled 2 people.

\section{Validity and Reliability Tests}

Based on the Table 1 above, it can be seen that all statements of each variable are declared valid because they have a positive relationship with the total construct score. This positive relationship occurs because each statement has a significance value below alpha $5 \%$ and the calculated $r$-value is greater than the value of $r$ table. The reliability test results in this study produced a Cronbach alpha value of each variable $>0.60$ so that all variables used were declared reliable.

\section{Hypothesis Test}

In this study, regression analysis is performed to determine whether there is an influence between the independent variables on the dependent variable. Multiple linear analysis is used to obtain a regression coefficient that will determine whether the hypothesis made will be accepted or rejected.

Based on the results of statistical calculations using the SPSS program as in Table 2, the multiple linear regression equation is obtained as follows.

$$
\mathrm{Y}=0,607+0,500 \mathrm{X} 1+0,402 \mathrm{X} 2+\mathrm{e}
$$

The results of regression testing for the first hypothesis in this study were conducted to find out which training and career development jointly influence employee performance.

Determination of the first hypothesis states that, if a significance value below $0.05 \mathrm{Ha}$ is accepted, it means training and career development together on employee performance. The results showed that training and career development jointly influenced employee performance because the significance value was 0,000 below 0.05 .. The coefficient of determination (R2) of 0.616 . This means that training and career development are able to explain variations in employee performance variables by $61.6 \%$ while the remaining $38.4 \%$ is explained by other variables not included in this research variable.

Other variables that might affect employee performance are motivation, organizational culture, and job satisfaction. The regression test results showed a 
significance value of 0,000 . The determination of the hypothesis states that if the sig value is below alpha $5 \%$ or 0.05 then $\mathrm{HO}$ is accepted, meaning that the training affects employee performance. The coefficient value is 0.500 , meaning that training has a positive effect on employee performance. The better training is given, the better the employee's performance.

The regression test results showed a significance value of 0,000 . The determination of the hypothesis states that if the significance value is below alpha $5 \%$ or 0.05 then $\mathrm{Ha}$ is accepted, meaning that career development affects employee performance. The coefficient value is 0.402 , meaning that career development has a positive effect on employee performance. The better the application of career development will improve employee performance. Hypothesis 1 test results can be seen that training affects employee performance. The coefficient value is 0.500 , meaning that training has a positive effect on performance the employee. The better training is given, the better the performance of employees.

The results of this study are relevant to research conducted by Julianry, Syarief, \& Affandi, (2017)) showed that good training impacts performance. Training and development are carried out in a separate location from the workplace. The program provides the expertise and knowledge for employees needed to carry out work separately. The abilities obtained from the training will be useful for employees in working, where the employee's abilities will increase the effectiveness and productivity of work. However, if the training provided does not provide an increase in the ability of employees, then the performance provided by employees will be mediocre. The results of hypothesis 2 can be seen that career development has a positive effect on employee performance. The better the application of career development will improve employee performance..

The results of this study are relevant to research conducted by Agung \& Widnyana (2020), Winda, Nayati \& Arik, (2017) showed that career development had a positive and significant effect on employee performance, has a significant and positive effect on performance and competence (Arifin et al,. 2020), has a positive and signicant effect on work engagement in the Employees (Rahman \& Syahrizal, 2019), (Simatupang at al,. 2017). This means that employees who want career advancement in their work will provide good performance to the organization. Jobs have the most influence on career development, because every time a different challenge arises, what is learned from work can be far more important than formally planned development activities. That way career development alone will give employees different knowledge from the work done before. Career development will also not occur if the performance carried out by employees is mediocre, improving employee careers will certainly have an impact on improving employee performance (Suryadi, Kemal, Setyanto, Rachmadtullah, 2020). The results of hypothesis 3 can be seen that training and career development have a joint effect on employee performance.

The coefficient of determination (R2) of 0.616 means that training and career development can explain variations in employee performance variables by $61.6 \%$ while the remaining $38.4 \%$ is explained by other variables not included in this research variable. Training and development provides employees with the skills and knowledge they need to carry out work at a time separate from their regular work time. Training is an effort to develop or explore the capabilities of a person so that they have the skills, ways of thinking and improving attitudes by what is needed by a particular company or agency so that they can solve problems that might be encountered in the future. While career development is an act of an employee to achieve his career plan, which is sponsored by the human resources department, managers or other parties.

Career training and development are interrelated in employee performance, where new types of skills acquired by employees will be needed for specific job requirements, where development will not occur if a person has not acquired the skills required by a particular position. With the skills gained by employees from training, employees will work diligently to achieve their career plans. Career plans can only be achieved if employees work well and always contribute to the organization. That way the ability and desire for a career will make employees work well.

\section{CONCLUSION}

Based on the results of data analysis in this study it can be concluded that training and career development affect employee performance. Training has a positive effect on employee performance. Career development has a positive effect on employee performance. To obtain useful results on an ongoing basis, some suggestions made for company development are employee performance variables that have the lowest average value on the effectiveness indicator, which means that cost-effectiveness has not been carried out by some employees in completing work. Therefore, management must implement an organizational culture wherein completing work the employee must be as effective as possible, both in terms of cost and time. Application of cost-effectiveness can be done by providing education both with circulars offices. The training variable has the lowest average value there are method indicators, which means that the training methods used have not been able to improve the ability of some employees. This requires a new method that can improve employee knowledge and abilities. Career development variables have the lowest average value found in the loyalty indicator, which means that loyalty to the organization does not become a benchmark in career development for some employees. This needs to develop employee careers that are prioritized by employees with long tenure and good performance for promotion. 


\section{REFERENCES}

Agung, A. A. P., \& Widnyana, I. W. (2020). The Effect of Career Development and Servant Leadership on Employee Performance with Work Motivation as an Intervening Variable in the Employment Agency and Human Resources Development Denpasar City. International Journal of Contemporary Research and Review, 11(01), 21741-21751.

Al-Khaled, A. A. S. (2019). The Significance of Training in Organizations on the Performance and Capabilities of Employees. Global Journal of Management And Business Research.

Anggi Bagus. (2020). Hubungan antara Lingkungan Kerja Non Fisik dengan Kinerja pada Karyawan Bagian Umum PT. Perkebunan Nusantara III (Persero) Medan (Vol. 1) Ebookbagdev.

Arifin, A. H., Raza, H., Saputra, J., \& Puteh, A. (2020). The Influence Of Recruitment And Career Development Towards Employee Performance: A Mediating Role Of Competence. Journal of Talent Development and Excellence, 12(1), 1040-1055.

Bajpai, N. (2009). Business Statistics. Pearson.

Elnaga, A., \& Imran, A. (2013). The effect of training on employee performance. European journal of Business and Management, 5(4), 137-147.

Naqvi, S. M. H., \& Khan, M. A. (2013). Employees training and organizational performance: Mediation by employees performance. Institute of Interdisciplinary Business Research, 5(4), 490-503.

Hutajulu, S. M., \& Supriyanto, S. (2013). Tinjauan Pelaksanaan Pelatihan Dan Pengembangan Karyawan Pada Pt. Inalum Kabupaten Batubara. Jurnal Bis-A: Jurnal Bisnis Administrasi, 2(2), 30-39.

Julianry, A., Syarief, R., \& Affandi, M. J. (2017). Pengaruh pelatihan dan motivasi terhadap kinerja karyawan serta kinerja organisasi kementerian komunikasi dan informatika. Jurnal Aplikasi Bisnis dan Manajemen (JABM), 3(2), 236.

Kemal, Isthifa., Suryadi., Rosyidi, Unifah. (2019). Management of Lecturers Resource Development at Higher Education. International Journal of Higger Education, 8(5), 246-256.

DOI: https://doi.org/10.5430/ijhe.v8n5p246

Lisdiani, V., \& Ngatno, N. (2017). Pengaruh Pengembangan Karir terhadap Kepuasan Kerja Karyawan Melalui Motivasi Kerja Sebagai Variabel Intervening (Studi Kasus Pada Hotel Grasia Semarang). Jurnal Ilmu Administrasi Bisnis, 6(4), 105-112.

Marwansyah. 2012. Manajemen Sumber Daya Manusia, Edisi Kedua, Alfabeta, Bandung

Memon, M. A., Salleh, R., \& Baharom, M. N. R. (2016). The link between training satisfaction, work engagement and turnover intention. European Journal of Training and Development.

Rahman, A., \& Syahrizal, S. (2019, April). Effect of Compensation and Career Development on Turnover Intention: Job Satisfaction as a Mediation
Variable. In $2^{\text {nd }}$ Padang International Conference on Education, Economics, Business and Accounting (PICEEBA-2 2018). Atlantis Press.

Sendawula, K., Kimuli, S. N., Bananuka, J., \& Muganga, G. N. (2018). Training, Employee Engagement and employee performance: Evidence from Uganda's health sector. Cogent Business \& Management, 5(1), 1470891.

Simatupang, D., Prayogo, D., \& Gupron, A. K. (2017). The Influence of Commitment, Job Competency and Career Development towards Job Satisfaction and Its Implications on the Performance of the Maritime Colleges' Permanent Lecturers in Jakarta. IOSR Journal Of Humanities And Social Science (IOSRJHSS), 22(9), 13-25.

Sulaksono, H. (2015). Budaya Organisasi dan Kinerja. Deepublish.

Trstenjak, M., \& Ćosić, P. (2018, January). Challenges of human resources managemen twith implementation of Industry 4.0. In IoTsm2018.

Suryadi., Kemal, Isthifa., Setyanto, Eddy., Racmadtullah, Reza. (2020). Career Development Management of Higher Education Lecturers in Indonesia, a Case Study at STKIP Bina Bangsa Getsempena Banda Aceh. International Journal of Innovation, Creativity and Change, 11(10), 499-515. https://ijicc.net/index.php/ijicc-editions/2020/163-vol11-iss-10.

Winda, O., Nayati, U. H., \& Arik, P. (2017). Impact of compensation and career development on job satisfaction and employees performance. Russian Journal of Agricultural and Socio-Economic Sciences, 64(4)

Wispandono, R. M. (2018). Buku Ajar Menguak Kemampuan Pekerja Migran. Deepublish. 